\title{
Efisiensi Penyerbukan oleh Penyerbuk Liar dan Lebah Tetragonula laeviceps pada Bunga Ranti dan Kacang Panjang
}

\author{
Pollination Efficiency of Wild Pollinators and Tetragonula laeviceps \\ on Black Nightshade and Yardlong Bean Flowers \\ Aena Sania Rahmani ${ }^{1}$, Ramadhani Eka Putra ${ }^{2 *}$, dan Wawan Gunawan ${ }^{2}$ \\ ${ }^{1}$ Jurusan Rekayasa Pertanian, Sekolah Ilmu dan Teknologi Hayati, Institut Teknologi Bandung \\ ${ }^{2}$ Sekolah Ilmu dan Teknologi Hayati, Institut Teknologi Bandung \\ Jl. Ganesa No. 10, Bandung 40132, Indonesia
}

Diterima 22 September 2020/Disetujui 4 Desember 2020

\begin{abstract}
Insect pollination is an effort to increase the efficiency of fruit production on limited land. The research aimed to observe the activity and pollination efficiency of wild insects and Tetragonula laeviceps on black nightshade plants and yardlong beans using an intercropping system in Sukawangi Village, Sumedang Regency from September to January 2020. Observations were made at 08:00-15:00 WIB during the flowering period. Observations were made on the treatment of T. laeviceps application, open-pollination, and self-pollination, each treatment consisting of 100 black nightshade flowers and 100 yardlong bean flowers and analyzed using one-way analysis of variance $(\alpha=0.05)$. Insect activity was measured based on flower handling time, foraging rate, visitation rate, and fruit set. Fruit quality was measured based on diameter, weight, length, and ${ }^{\circ}$ Brix. The study recorded 3 visiting insect flowers in black nightshade and yardlong, which potentially act as a pollinator, with varying visit patterns in open-pollination. The highest fruit set efficiency of black nightshade occurred in the application treatment of $\underline{T}$. laeviceps and yardlong beans in the open-pollination treatment. There was significant in ${ }^{\circ}$ Brix of black nightshade fruit and yardlong beans, whereas self-pollination only yielded significantly longer fruit in yardlong beans.

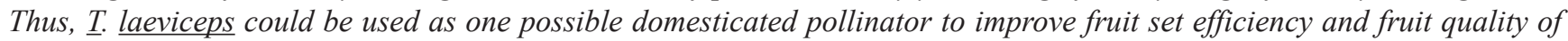
black nightshade and yardlong beans.
\end{abstract}

Keywords: fruit quality, fruit set, insect activity

\section{ABSTRAK}

Penyerbukan serangga merupakan salah satu upaya peningkatan efisiensi produksi tanaman berbuah pada lahan terbatas. Penelitian bertujuan mengamati aktivitas dan efisiensi penyerbukan serangga liar dan Tetragonula laeviceps pada tanaman ranti dan kacang panjang dengan sistem tanam tumpang sari di Desa Sukawangi, Kabupaten Sumedang pada bulan September hingga Januari 2020. Pengamatan dilakukan pada pukul 08:00-15:00 WIB selama periode perbungaan. Pengamatan dilakukan pada perlakuan aplikasi $\underline{\text { T. }}$ laeviceps, open-pollination, dan self-pollination, masing-masing perlakuan terdiri atas 100 bunga ranti dan 100 bunga kacang panjang dan dianalisis menggunakan one way analysis of variance $(\alpha=0.05)$. Aktivitas serangga diukur berdasarkan flower handling time, foraging rate, visitation rate, dan fruit set. Kualitas buah diukur berdasarkan diameter, bobot, panjang, dan ${ }^{\circ}$ Brix. Hasil penelitian ditemukan masing-masing tiga serangga pengunjung berpotensi polinator pada ranti dan kacang panjang dengan pola kunjungan bervariasi pada openpollination. Efisiensi fruit set tertinggi ranti terjadi pada perlakuan aplikasi $\underline{T}$. laeviceps dan kacang panjang pada perlakuan open-pollination. Terdapat perbedaan nyata pada ${ }^{\circ}$ Brix buah ranti dan kacang panjang, sedangkan self-pollination hanya menghasilkan buah yang secara signifikan lebih panjang pada kacang panjang. Dengan demikian, $\underline{\text { T. }}$ laeviceps dapat dijadikan salah satu alternatif serangga penyerbuk terdomestikasi dalam upaya efisiensi fruit set dan kualitas buah tanaman ranti dan kacang panjang.

Kata kunci: aktivitas serangga, fruit set, kualitas buah

\footnotetext{
* Penulis untuk korespondensi. e-mail: ramadhani@sith.itb.ac.id
} 


\section{PENDAHULUAN}

Ranti (Solanum nigrum L.) dengan nama lain leunca dan kacang panjang (Vigna unguiculata ssp. sesquipedalis (L.) Verdc.) merupakan sayuran indigenous yang dikonsumsi sebagai sayuran lalapan yang menjadi salah satu ciri dari budaya kuliner Jawa Barat (Yulianti et al., 2018). Walaupun demikian, ranti seringkali disebut sebagai sayuran minor karena selain ranti belum mampu bersaing dengan sayuran mayor (seperti bayam, kangkung, selada) yang sudah berkembang lama diantaranya karena ranti memiliki rasa yang kurang disukai (Soetiarso, 2010). Di sisi lain, kacang panjang juga digolongkan sebagai sayuran minor walaupun memiliki kandungan protein yang tinggi (23-29\%), dengan potensi sekitar 35\%, dan memiliki kemampuan untuk mengikat nitrogen dari atmosfer sehingga menjadikannya sebagai salah satu tanaman yang dapat memperbaiki tanah yang buruk (Ige et al., 2011). Pendekatan yang dapat dilakukan untuk meningkatkan pemanfaatan dari kedua jenis tanaman ini adalah dengan meningkatkan produktivitas (Reswari et al., 2019) tanpa meningkatkan biaya produksi sehingga keuntungan dapat diperoleh dalam sistem budidaya diantaranya dengan mekanisme tumpang sari (untuk mengefisienkan penggunaan lahan) dan peningkatan jumlah buah yang dihasilkan.

Jumlah buah yang dihasilkan pada tanaman berbuah dapat ditingkatkan dengan peningkatan keberhasilan penyerbukan (Sawe et al., 2020) yang secara alami banyak dibantu serangga (Proctor et al., 2012). Hal yang menarik adalah, walaupun sebagian besar tanaman budidaya merupakan tanaman yang dapat melakukan penyerbukan sendiri keberadaan kunjungan serangga dapat meningkatkan produktivitas dari tanaman tersebut (Pellegrino et al., 2005). Akan tetapi, seringkali kondisi agroekosistem tidak menunjang keberadaan serangga-serangga penyerbuk liar (Connelly et al., 2015). Peran dari serangga-serangga liar ini selanjutnya dapat digantikan dengan lebah madu yang telah didomestikasi (Ige et al., 2011). Secara garis besar terdapat dua jenis lebih madu yang telah didomestikasikan, yaitu lebah madu umum (terutama dari genus Apis) dan lebah tidak bersengat

Pada penelitian ini, dilakukan aplikasi dari kelompok lebah lokal tidak bersengat sebagai pengganti dari lebah madu. Lebah ini yang memiliki potensi sebagai agen penyerbuk pada pertanian lokal (Putra et al., 2017) dan salah satu spesies yang umum ditemukan di Jawa Barat adalah Tetragonula. laeviceps Smith. Berdasarkan hal di atas maka tujuan dari penelitian ini adalah untuk mendapatkan informasi terkait peran serangga penyerbuk liar dan $T$. laeviceps sebagai agen penyerbuk pada pembentukan buah yang dihasilkan pada budidaya tumpang sari tanaman ranti dan kacang panjang.

\section{BAHAN DAN METODE}

Penelitian dilaksanakan bulan September 2019 sampai dengan Januari 2020 di Dusun Margabakti, Desa
Sukawangi, Kecamatan Pamulihan, Kabupaten Sumedang, Jawa Barat. Selama masa pengamatan, pola iklim mikro di lokasi penelitian yang diambil dari AccuWeather (Tabel 1).

Penelitian ini menggunakan benih kacang panjang yang diproduksi oleh PT East West Seed sedangkan benih ranti yang digunakan adalah varietas lokal. Kedua jenis benih merupakan benih yang paling umum dibudidayakan pada lokasi penelitian.

Pengolahan tanah dilakukan 2 minggu sebelum tanam. Penanaman benih dilakukan pada bedengan berukuran 6 $\mathrm{m} \times 1.4 \mathrm{~m}$ dan ditutupi dengan mulsa plastik. Penanaman dilakukan dengan sistem tanam tumpang sari, terdiri atas 10 tanaman ranti dan 10 tanaman kacang panjang pada jarak tanam $60 \mathrm{~cm}$ x $70 \mathrm{~cm}$ (Gambar 1). Ditanam 2 buah bibit ranti dan diselingi 2 butir biji kacang panjang yang langsung ditambahkan pada lubang tanam.

Tanaman dibagi menjadi 3 kelompok perlakuan, yaitu (1) Penyerbukan sendiri (SP), (2) T. laeviceps (TP), dan (3) penyerbukan terbuka (OP). Perbedaan pada pola pembentukanbuahpadaketigakelompokadalah(1)kelompok SP, bunga diasumsikan melakukan proses penyerbukan sendiri dengan serbuk sari yang berasal dari bunga yang sama atau kelompok bunga yang berdekatan, (2) kelompok OP, bunga diasumsikan mendapatkan servis penyerbukan dari serangga-serangga liar yang mengunjungi bunga, dan (3) kelompok TP, bunga diasumsikan mendapatkan servis penyerbukan dari koloni T. laeviceps dan penelitian untuk kelompok ini dilakukan di dalam screenhouse agar proses penyerbukan pada bunga ranti dan kacang panjang hanya dilakukan oleh $T$. laeviceps. T. laeviceps diintroduksikan saat mulai pengamatan sebanyak tiga stup T. laeviceps. Sebelum proses pengamatan, 100 bunga yang belum mekar (masing-masing terdiri atas 10 bunga untuk ranti dan 45 bunga untuk kacang panjang) pada 10 tanaman ranti dan 20 tanaman kacang panjang yang dipilih secara acak, digunakan sebagai sampel pada setiap perlakuan. Bakal bunga tersebut dibungkus dengan kain kasa (diameter lubang $1 \mathrm{~mm}$ ) dan diberi tanda dengan label ukuran $1 \mathrm{~cm} \mathrm{x}$ $5 \mathrm{~cm}$. Saat bunga mekar, kain kasa dibuka untuk kelompok OP dan TP sementara kain kasa tidak dibuka pada kelompok SP. Pengamatan terhadap proses penyerbukan oleh serangga dilakukan mulai pukul 08:00-16:00 WIB dan dilakukan hingga bunga rontok (Klein et al., 2003). Pengamatan pada interaksi ini dilakukan menggunakan metode scan sampling, yaitu pengamatan selama 5 menit setiap jam pada semua blok. Pengamatan yang dilakukan terkait dengan interaksi polinator dan bunga disajikan dalam bentuk

\section{Jumlah Kunjungan per Bunga (Visitation Rate, VR)}

Jumlah kunjungan satu jenis serangga dibandingkan dengan total kunjungan seluruh serangga pada bunga selama masa pengamatan (waktu pengamatan 5 menit per tanaman sampel). Data disajikan dalam bentuk persen (\%) (Klein et al., 2003). 
Tabel 1. Data variabel iklim mikro pada area pengamatan di Desa Sukawangi, Kecamatan Pamulihan, Kabupaten Sumedang, Jawa Barat

\begin{tabular}{lrrrrrrrr}
\hline & \multicolumn{7}{c}{ Jam } \\
\cline { 2 - 8 } Variabel & $08: 00-$ & $09: 00-$ & $10: 00-$ & $11: 00-$ & $12: 00-$ & $13: 00-$ & $14: 00-$ & $15: 00-$ \\
& $09: 00$ & $10: 00$ & $11: 00$ & $12: 00$ & $13: 00$ & $14: 00$ & $15: 00$ & $16: 00$ \\
\hline Suhu $\left({ }^{\circ} \mathrm{C}\right)$ & 24 & 25 & 27.5 & 27 & 27.5 & 26.5 & 26 & 24.5 \\
Angin (kph TL) & 6 & 6 & 6.5 & 7 & 8 & 9 & 8 & 7 \\
Kelembaban (\%) & 76 & 74 & 58.5 & 60 & 63.5 & 67.5 & 71 & 80 \\
Indeks UV maks & 2 & 2 & 5.5 & 8 & 9 & 8 & 5.5 & 2.5 \\
Tutupan awan (\%) & 95 & 94 & 59.5 & 64.5 & 77 & 74 & 76.5 & 78.5 \\
Intensitas sinar (lux) & 2,000 & 2,000 & 5,500 & 8,000 & 9,000 & 8,000 & 5,500 & 2,500 \\
\hline
\end{tabular}

Waktu yang Dihabiskan pada Bunga (Flower Handling Time, FHT)

Waktu yang dihabiskan oleh satu individu lebah di bunga sejak kedatangan hingga meninggalkan bunga. Data disajikan dalam bentuk detik (s) (Wulandari et al., 2017). Jumlah sampel serangga yang dijadikan dasar perhitungan ditentukan pada jumlah individu serangga yang melakukan aktivitas di bunga pada tanaman sampel.

\section{Jumlah Bunga yang Dikunjungi (Foraging Rate, FR)}

Jumlah bunga yang dikunjungi per satuan waktu (dalam penelitian ini digunakan satuan menit) (Wulandari et al., 2017). Pengamatan dilakukan pada satu tanaman dan nilai ini berdasarkan pada jumlah dari bunga sampel yang dikunjungi oleh satu individu serangga. Jumlah sampel serangga yang dijadikan dasar perhitungan ditentukan pada jumlah individu serangga yang melakukan aktivitas di bunga.

\section{Persentase Buah yang Terbentuk (Fruit Set)} rumus:

Persentase buah yang terbentuk dihitung dengan

$$
\text { Fruit set }=\frac{\text { Jumlah buah }}{\text { Jumlah bunga }} \times 100 \%
$$

Perhitungan dilakukan pada seluruh bunga yang menjadi sampel

\section{Karakteristik dari Buah}

Terdapat 3 komponen yang diukur terkait dengan karakteristik buah, yaitu bobot buah (diukur dalam satuan gram), dimensi dari buah (panjang dan diameter buah diukur pada satuan $\mathrm{cm}$ dan $\mathrm{mm}$, secara berurutan), dan kandungan senyawa terlarut pada buah. Pada penelitian ini, pengukuran kandungan senyawa pada buah difokuskan pada jumlah kandungan sukrosa (g $100 \mathrm{~g}^{-1}$ larutan) yang diukur menggunakan refraktrometer untuk menghasilkan
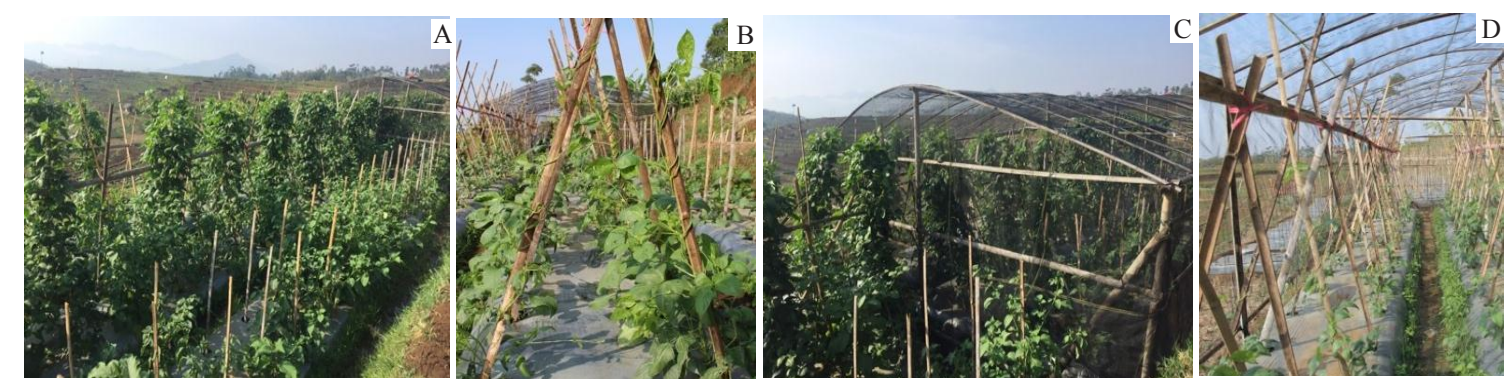

Pola penanaman tumpang sari ranti dan kacang Panjang (A dan B) di luar screen house, (C dan D) di dalam screen house

\begin{tabular}{|c|c|c|c|c|c|c|c|c|c|}
\hline$\pi$ & $\approx$ & $\pi$ & $\underset{\sim}{\overparen{J}}$ & 耗 & $\widetilde{c}$ & 死 & 己 & 不 & $\approx$ \\
\hline$\underset{0}{\mathbb{C}}$ & $\underset{0}{\nabla}$ & ন্তু & $\underset{\infty}{\not \infty}$ & 不 & $\nabla$ & $\underset{\mathbb{A}}{\overparen{A}}$ & $\ddot{\nabla}$ & 五 & J \\
\hline
\end{tabular}

Skema pengambilan sampel pada perlakuan open dan self-pollination

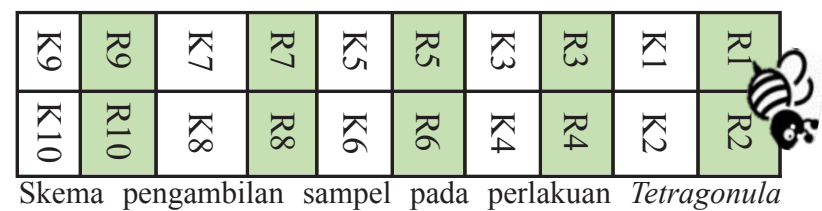

laeviceps

Gambar 1. Skema penelitian. $\mathrm{L}=($ Ranti); $\mathrm{K}=$ Kacang panjang; Panjang bedengan $=6 \mathrm{~m}$; Lebar bedengan $=1.4 \mathrm{~m}$; Jarak antar tanaman leunca $($ ranti) $=60 \mathrm{~cm}$; Jarak antar tanaman kacang panjang $=60 \mathrm{~cm}$; Jarak antar tanaman ranti dan kacang panjang $=70 \mathrm{~cm}$ 
nilai dalam satuan Brix. Nilai Brix dapat digunakan untuk menunjukkan kesuksesan dalam proses penyerbukan yang dilaporkan berbanding lurus dengan kandungan sukrosa pada buah hasil penyerbukan yang tidak memiliki rasa manis (contoh: mentimun) (Gajc-Wolska et al., 2011).

Analisis data dilakukan untuk mendapatkan informasi terkait pengaruh dari proses penyerbukan pada produktivitas dan kualitas produk hasil proses budidaya. Tingkat normalitas data diuji menggunakan Uji Saphiro-Wilk, serta uji homogenitas. Data yang bersifat normal selanjutnya dianalisis menggunakan one way analysis of variance (anova) dengan tingkat kepercayaan 95\% $(\alpha=0.05)$ dengan uji lanjutan Tukey.

\section{HASIL DAN PEMBAHASAN}

\section{Aktivitas Serangga Penyerbuk Liar pada Tanaman Ranti}

Terdapat 3 spesies serangga yang mengunjungi bunga ranti, yaitu Xylocopa sp., Amegilla sp., dan Sphaerophoria scripta selama masa penelitian (Tabel 2). Di antara ketiga serangga tersebut, Xylocopa sp. memiliki nilai FHT, FR, dan VR paling rendah sedangkan $S$. scripta memiliki nilai tertinggi untuk ketiga variabel (Tabel 2). Puncak dari FHT dan FR pada semua serangga terjadi pada siang hari antara 10:00-12:00 (Gambar 2).

Di antara ketiga serangga pengunjung bunga ranti, $S$. scripta memiliki pola kunjungan yang relatif stabil yang berkaitan dengan karakteristik dari S. scripta yang termasuk pada kelompok lalat (Diptera: syrphidae) berukuran kecil sehingga memiliki kebutuhan energi yang lebih rendah dan preferensi dari kelompok ini untuk mengkonsumsi serbuk sari (Ssymack dan Gilbert, 1993). Karena produksi serbuk sari relatif tidak dipengaruhi oleh waktu, hal ini memungkinkan serangga ini untuk terus memanen reward yang diberikan oleh bunga ranti.

\section{Aktivitas Lebah Tetragonula laeviceps pada Tanaman Ranti}

Bila dibandingkan dengan serangga liar, interaksi $T$. laeviceps dan bunga ranti serupa dengan pola interaksi dari S. scripta dengan perbedaan besar pada FR yang jauh lebih tinggi (Tabel 1). Pola harian interaksi dengan bunga ranti menunjukkan puncak aktivitas pada pukul 09:00-13:00 (Gambar 2) yang merupakan pola umum dari aktivitas lebah tidak bersengat pada bunga sebagaimana dilaporkan pada beberapa penelitian terdahulu (Stein dan Hansen, 2011; Polatto et al., 2012). Pola kunjungan yang relatif stabil oleh serangga ini pada bunga ranti kemungkinan berkaitan dengan sifat sosial dari serangga ini (Putra et al., 2017) dan kondisi lingkungan di dalam screen house yang relatif lebih terlindungi terutama dari efek pergerakan udara.

Pola kunjungan dari serangga pengunjung bunga ranti dapat berkaitan dengan (1) pengaruh dari kondisi iklim mikro pada lokasi budidaya dimana beberapa penelitian melaporkan pengaruh dari faktor lingkungan (seperti suhu dan kelembaban udara serta kecepatan angin) pada interaksi antara serangga penyerbuk dan bunga (Descamps et al., 2018; Crall et al., 2020). Pada penelitian ini, data lingkungan menunjukkan bahwa kecepatan angin, kelembaban udara, dan tingkat tutupan awan kemungkinan menjadi faktor lingkungan penentu pola kunjungan serangga penyerbuk liar (Tabel 1), (2) kuantitas dan kualitas reward dari bunga bagi serangga (Potts et al., 2010; Ruslan et al., 2015), dan (3) karakteristik dari serangga terkait dengan kebutuhan energi (Tan et al., 2015) maupun apakah serangga hidup dalam koloni atau bersifat soliter (Leksikowati et al., 2018; Hendriksma et al., 2019). Ketiga hipotesis ini perlu diuji pada penelitian lebih lanjut untuk mendapatkan pemahaman lebih baik pada sistem penyerbukan pada ranti.

\section{Aktivitas Serangga Penyerbuk Liar pada Tanaman Kacang Panjang}

Terdapat 3 jenis serangga yang mengunjungi bunga kacang panjang, yaitu Xylocopa sp., T. laeviceps, dan Lampides boeticus. Diantara ketiga jenis serangga ini, L. boeticus merupakan serangga dengan FHT terlama, sedangkan T. laeviceps sebagai serangga dengan nilai VR tertinggi (Tabel 3). Pola kunjungan dari setiap serangga relatif tidak stabil yang ditandai dengan 2 puncak kunjungan pada bunga, dimana Xylocopa sp. dan T. laeviceps memiliki puncak kunjungan awal pada pukul 08:00-10:00 sedangkan L. boeticus pada siang hari bersamaan dengan puncak kedua dari T. laeviceps (11:00-12:00) (Gambar 3). Xlocopa sp. membutuhkan gula pada nektar sebagai sumber energi sedangkan L. boeticus dan T. laeviceps yang membutuhkan energi lebih kecil memiliki pola kunjungan lebih stabil. Selain itu, selain struktur alat mulut (pada L. boeticus) dan ukuran tubuh yang lebih kecil (pada T. laeviceps)

Tabel 2. Rata-rata aktivitas serangga pada bunga ranti pada perlakuan open-pollination dan aplikasi Tetragonula laeviceps

\begin{tabular}{lcccr}
\hline Polinator & Waktu & FHT (s) & FR (bunga per menit) & VR (\%) \\
\hline Xylocopa sp. & $08: 00-14: 00$ & $4.49 \pm 4.75$ & $1.4 \pm 0.59$ & $8.53 \pm 1.03$ \\
Amegilla sp. & $08: 00-15: 00$ & $8.14 \pm 4.75$ & $2.3 \pm 0.99$ & $37.74 \pm 3.48$ \\
Sphaerophoria scripta & $08: 00-15: 00$ & $11.83 \pm 7.26$ & $2.0 \pm 0.55$ & $53.72 \pm 4.72$ \\
Tetragonula laeviceps & $08: 00-15: 00$ & $11.20 \pm 3.61$ & $3.4 \pm 1.07$ & 100 \\
\hline
\end{tabular}

Keterangan: FHT = waktu yang dihabiskan pada bunga (flower handling time), $\mathrm{FR}=$ jumlah bunga yang dikunjungi (foraging rate), $\mathrm{VR}=$ jumlah kunjungan per bunga (visitation rate) 

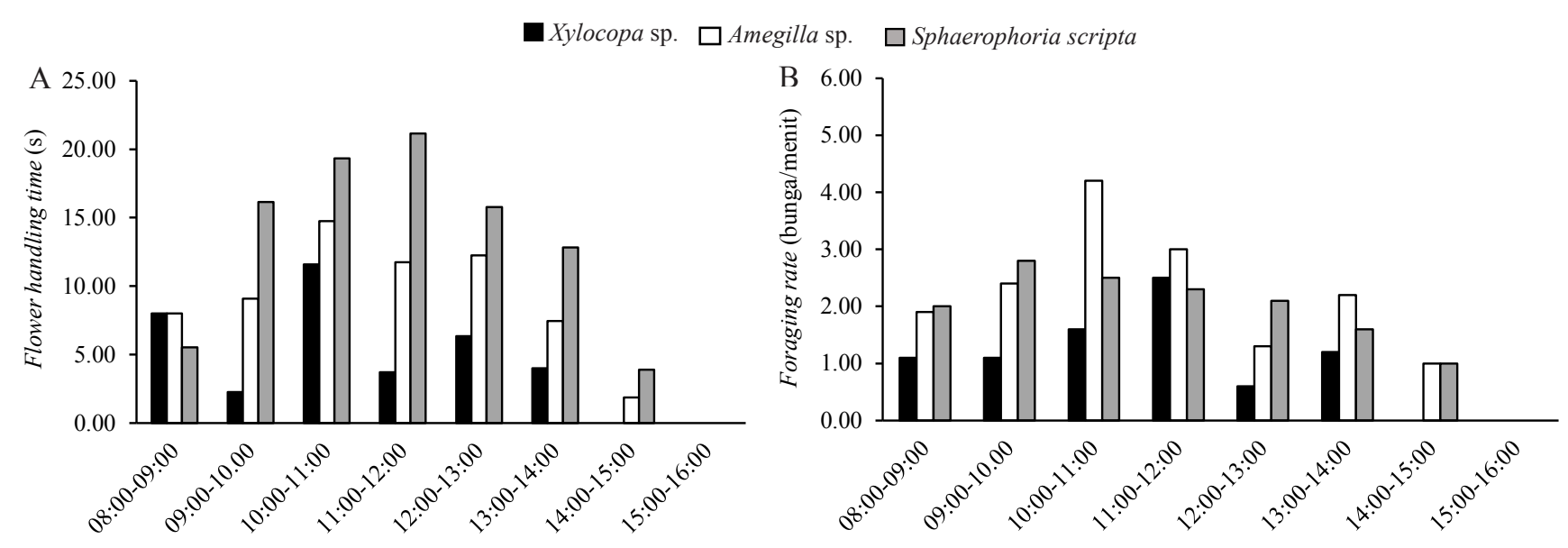

Tetragonula laeviceps
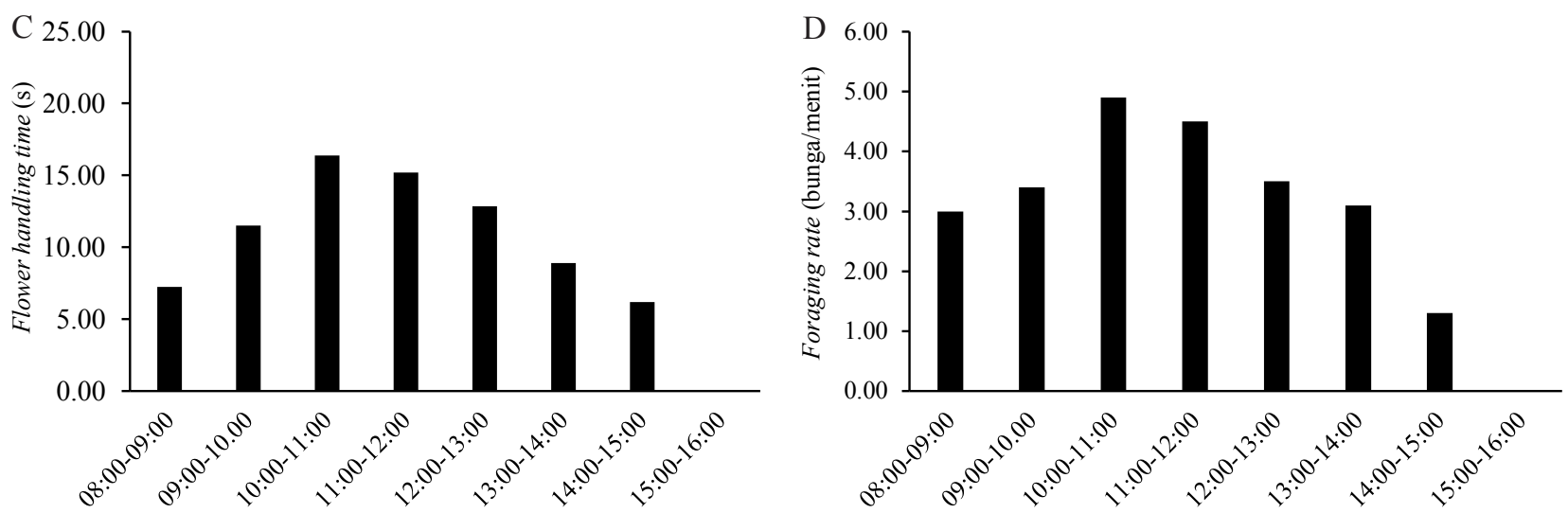

Gambar 2. (A) dan (C) pola flower handling time pada perlakukan penyerbukan terbuka (open pollination) dan penyerbukan dengan Tetragonula laeviceps serta (B) dan (D) foraging rate pada perlakuan penyerbukan terbuka pada penyerbukan terbuka (open pollination) dan penyerbukan dengan Tetragonula laeviceps untuk tanaman ranti

lebih memungkinkan kedua serangga ini untuk mengakses nektar pada lokasi produksi yang relatif sulit dijangkau oleh Xylocopa sp. yang berukuran lebih besar. Perbedaan pada pola kunjungan ini kemungkinan terkait dengan konsentrasi gula pada nektar yang dihasilkan oleh bunga dimana konsentrasi gula tertinggi dihasilkan pada pagi hari dan terendah pada tengah hari, sebagaimana dilaporkan pada cowpea, subspesies kerabat dari kacang panjang (Fohouo et al., 2009).

\section{Aktivitas Lebah Tetragonula laeviceps pada Tanaman Kacang Panjang}

Rata-rata aktivitas kunjungan T. laeviceps pada bunga ranti terjadi pada pukul 08.00 hingga 15.00 dengan puncak tertinggi pada pukul 10:00-12:00 yang serupa dengan hasil penelitian Stein dan Hensen (2011). Bila dibandingkan dengan T. laeviceps yang berada di sistem alami, FHT dan FR pada sistem tertutup relatif stabil (Gambar 3).

Tabel 3. Rata-rata aktivitas serangga pada bunga kacang panjang pada perlakuan open-pollination dan aplikasi Tetragonula laeviceps

\begin{tabular}{lcccc}
\hline Polinator & Waktu & FHT (s) & FR (bunga per menit) & VR (\%) \\
\hline Xylocopa olivaceae & $08: 00-15: 00$ & $13.25 \pm 8.92$ & $1.0 \pm 0.9$ & $11.11 \pm 1.13$ \\
Tetragonula laeviceps & $08: 00-14: 00$ & $11.74 \pm 9.11$ & $2.1 \pm 1.2$ & $55.56 \pm 3.59$ \\
Lampides boeticus & $08: 00-15: 00$ & $27.17 \pm 16.27$ & $2.0 \pm 1.0$ & $33.33 \pm 3.44$ \\
Tetragonula laeviceps & $08: 00-15: 00$ & $12.28 \pm 3.61$ & $2.03 \pm 0.90$ & 100 \\
\hline
\end{tabular}

Keterangan: FHT = waktu yang dihabiskan pada bunga (flower handling time), $\mathrm{FR}=$ jumlah bunga yang dikunjungi $($ foraging rate), $\mathrm{VR}=$ jumlah kunjungan per bunga (visitation rate) 
A

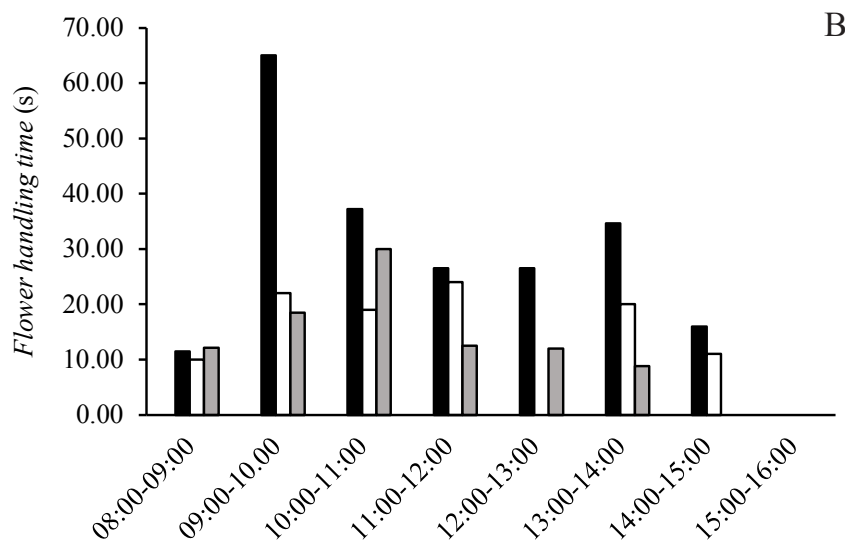

$\mathrm{B}$

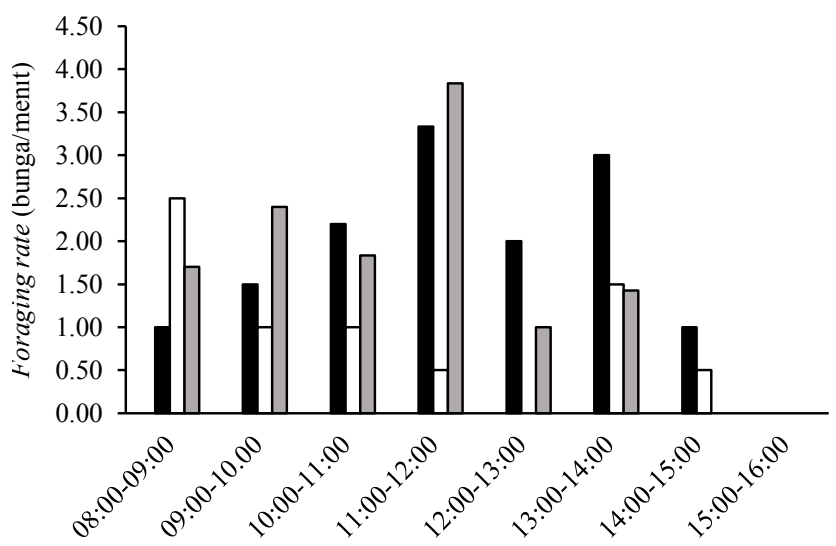

Tetragonula laeviceps
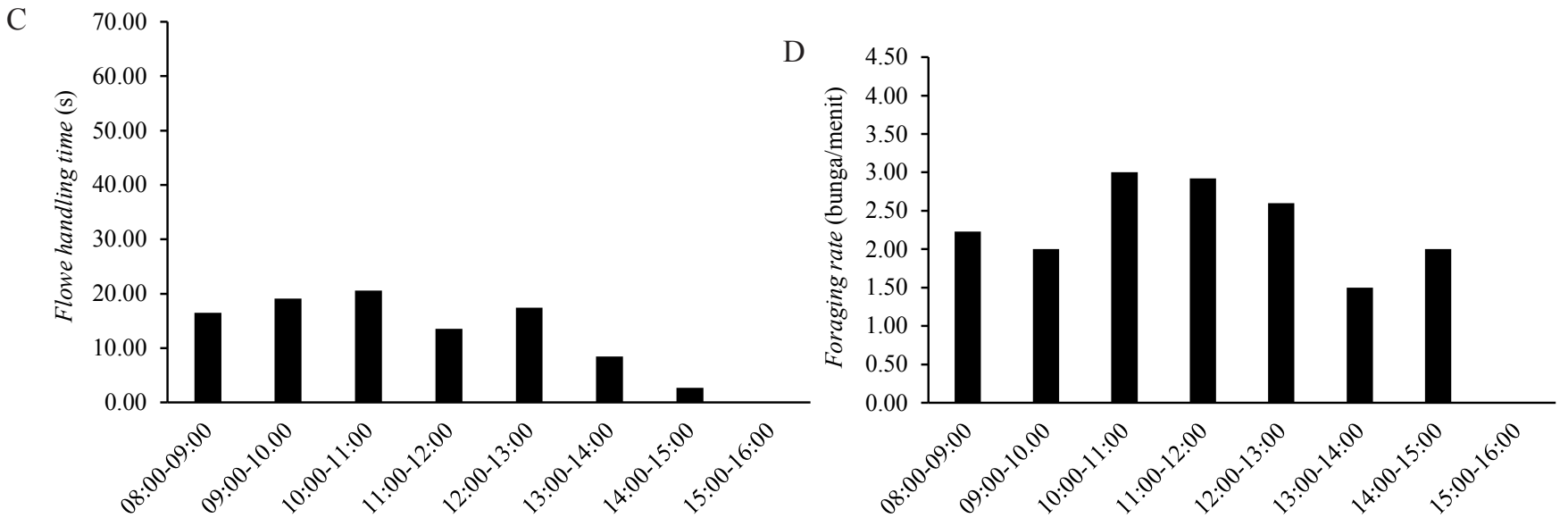

Gambar 3. (A) dan (C) pola flower handling time pada perlakukan penyerbukan terbuka (open pollination) dan penyerbukan dengan Tetragonula laeviceps serta (B) dan (D) foraging rate pada perlakuan penyerbukan terbuka pada penyerbukan terbuka (open pollination) dan penyerbukan dengan Tetragonula laeviceps untuk tanaman kacang panjang

\section{Efisiensi Penyerbukan}

Pada tanaman ranti, kelompok TP menghasilkan fruit set tertinggi dibandingkan pada kelompok OP dan secara signifikan berbeda dengan hasil pada kelompok SP (Tabel 4). Di sisi lain, kelompok OP pada tanaman kacang panjang memiliki tingkat fruit set paling tinggi, walaupun tidak signifikan, bila dibandingkan dengan fruit set pada kelompok TP dan SP (Tabel 4). Data ini menunjukkan bahwa keberadaan serangga penyerbuk dapat meningkatkan fruit set dari tanaman yang dapat melakukan penyerbukan sendiri.
Tanaman ranti termasuk pada kelompok Solanum yang didominasi dengan spesies yang melakukan penyerbukan sendiri (Kowalska, 2008), namun penelitian oleh Venkateswarlu dan Rao (1972) melaporkan bahwa terdapat kemungkinan bahwa sebagian S. nigrum memiliki sistem penyerbukan silang. Hasil penelitian ini mengkonfirmasi kemungkinan terdapatnya $S$. nigrum lokal Indonesia yang memiliki sistem penyerbukan silang, hal serupa juga dilaporkan pada penelitian di Afrika (Oyelana dan Ogunwenmo, 2012). Dengan membandingkan nilai fruit set antara kelompok penyerbukan terbuka dan penyerbukan $T$. laeviceps maka T. laeviceps dapat berperan sebagai serangga

Tabel 4. Efisiensi penyerbukan pada tanaman ranti dan kacang panjang

\begin{tabular}{lccc}
\hline \multirow{2}{*}{ Tanaman } & \multicolumn{3}{c}{ Efisiensi penyerbukan (\%) } \\
\cline { 2 - 4 } & Open-pollination & Aplikasi T. laeviceps & Self-pollination \\
\hline Ranti & $82 \pm 13.27 \mathrm{a}$ & $89 \pm 9.43 \mathrm{a}$ & $68 \pm 10.77 \mathrm{~b}$ \\
Kacang panjang & $70 \pm 14.83 \mathrm{a}$ & $64 \pm 10.2 \mathrm{a}$ & $42 \pm 14.70 \mathrm{a}$ \\
\hline
\end{tabular}

Keterangan: Huruf yang berbeda pada kolom yang sama menunjukkan nilai yang berbeda berdasarkan analisis ragam yang dilanjutkan dengan uji Tukey dengan selang kepercayaan 95\% 
Tabel 5. Perbandingan bobot, diameter, dan ${ }^{\circ}$ Brix buah untuk tanaman ranti dan kacang panjang pada model penyerbukan yang berbeda

\begin{tabular}{|c|c|c|c|c|}
\hline Perlakuan & Bobot buah (g) & Diameter buah $(\mathrm{mm})$ & ${ }^{\circ}$ Brix & Panjang buah $(\mathrm{cm})$ \\
\hline \multicolumn{5}{|l|}{ Ranti } \\
\hline Open-pollination & $1.44 \pm 0.13 \mathrm{a}$ & $14.01 \pm 0.44 \mathrm{a}$ & $2.02 \pm 1.07 \mathrm{a}$ & \\
\hline T. laeviceps & $1.41 \pm 0.26 \mathrm{a}$ & $13.86 \pm 0.05 \mathrm{a}$ & $3.42 \pm 0.30 \mathrm{~b}$ & \\
\hline Self-pollination & $1.21 \pm 0.12 \mathrm{a}$ & $13.08 \pm 0.58 \mathrm{a}$ & $1.83 \pm 0.85 \mathrm{a}$ & \\
\hline \multicolumn{5}{|l|}{ Kacang panjang } \\
\hline Open-pollination & $20.76 \pm 5.64 \mathrm{a}$ & $6.41 \pm 0.81 \mathrm{a}$ & $2.03 \pm 1.05 \mathrm{a}$ & $58.57 \pm 7.15 \mathrm{a}$ \\
\hline T. laeviceps & $18.24 \pm 9.99 \mathrm{a}$ & $6.03 \pm 1.03 \mathrm{a}$ & $3.41 \pm 0.29 b$ & $59.42 \pm 5.32 \mathrm{a}$ \\
\hline Self-pollination & $20.30 \pm 7.41 \mathrm{a}$ & $6.22 \pm 0.76 \mathrm{a}$ & $1.83 \pm 0.85 \mathrm{a}$ & $46.35 \pm 5.76 \mathrm{~b}$ \\
\hline
\end{tabular}

Keterangan: Huruf yang berbeda pada kolom dan tanaman yang sama menunjukkan nilai yang berbeda berdasarkan analisis ragam yang dilanjutkan dengan uji Tukey dengan selang kepercayaan 95\%

penyerbuk setara dengan Xylocopa sp., yang dikenal dengan kemampuannya untuk melakukan buzz-pollination, sebagai salah satu serangga penyerbuk terbaik bagi kelompok Solanum (De Luca dan Vallejo-Marin, 2013).

Hal serupa juga ditunjukkan pada hasil pengamatan efisiensi penyerbukan pada tanaman kacang panjang dimana keberadaan serangga meningkatkan fruit set, bila dibandingkan dengan buah dari proses penyerbukan sendiri, yang juga dilaporkan oleh Normasari (2015) dan Stephanie et al. (2015). Hasil penelitian ini mendukung penelitian yang menunjukkan efek positif dan variasi dari serangga penyerbuk terhadap produksi buah (Abrol et al., 2019). Sementara itu, keberadaan Xylocopa sp. yang memiliki ukuran tubuh besar, sebagai pengunjung dapat memberikan pengaruh positif pada kesuksesan proses penyerbukan pada tanaman kacang panjang sebagaimana dilaporkan oleh Wousla et al. (2019).

\section{Perbandingan Hasil Produksi dan Kualitas Buah}

Secara garis besar, pada tanaman ranti dan kacang panjang, keberadaan serangga penyerbuk memberikan efek positif pada bobot buah dan diameter buah, walaupun tidak signifikan, serta efek peningkatan nilai brix secara signifikan pada kelompok yang mendapatkan bantuan penyerbukan oleh T. laeviceps (one way anova, $\mathrm{P}<0.05$ ) (Tabel 5). Nilai Brix menunjukkan jumlah kandungan terlarut (total soluble solid content) di dalam buah (terutama gula) yang secara sederhana mengindikasikan kualitas nutrisi dari buah (Karapanos et al., 2016). Peningkatan Brix sebagai dampak dari aktivitas serangga penyerbuk pada bunga juga dilaporkan pada berbagai komoditas pertanian (Bommarco et al., 2012; Klatt et al., 2014). Udayani et al. (2020) menjelaskan kandungan sukrosa Solanum melongena L. sebagai indikator kematangan pada buah berkualitas lebih baik dibandingkan dengan buah yang dihasilkan dari penyerbukan sendiri, serta nilai Brix yang tinggi juga dapat juga mengindikasikan pematangan buah yang lebih cepat pada buah dari kelompok kacang-kacangan (De Cillis et al., 2019).
Pada tanaman kacang panjang, buah kacang panjang perlakuan OP menunjukkan gejala serangan hama sedangkan pada perlakuan aplikasi $T$. laeviceps, buah kacang panjang terlihat mulus dan tidak ada lubang-lubang (pengamatan pribadi). Hal ini dapat disebabkan oleh L. boeticus, salah satu serangga yang mengunjungi bunga kacang panjang, yang dilaporkan sebagai salah satu hama yang dapat merusak bunga dan polong pada kacang panjang (Al-Janabi dan Al-Karboli, 2017). Apakah proses peletakan telur juga dilakukan bersamaan dengan kunjungan pada bunga merupakan hal yang perlu diteliti lebih lanjut.

\section{KESIMPULAN}

Keberadaan serangga penyerbuk liar memberikan efek positif pada produktivitas dari tanaman ranti dan kacang panjang, walaupun tidak signifikan. Peran dari serangga penyerbuk liar yang relatif sulit ditemukan pada lahan pertanian konvensional dapat digantikan oleh lebah tidak bersengat (Tetragonula laeviceps) akan tetapi tidak secara sempurna dapat menggantikan efek menguntungkan dari variasi hewan penyerbuk terhadap produktivitas. Perbaikan kondisi lingkungan sekitar daerah budidaya (terutama tanaman buah) yang menunjang dan mengundang kedatangan serangga penyerbuk liar, aplikasi lebah terdomestikasi, dan metoda perlindungan hama yang aman terhadap serangga-serangga penyerbuk dapat meningkatkan kesinambungan dari sistem usaha dan memungkinkan peningkatkan keuntungan dari petani.

\section{UCAPAN TERIMA KASIH}

Penelitian ini sebagian dibiayai oleh hibah program Indofood Riset Nugraha 2019/2020 dari PT Indofood Sukses Makmur Tbk. yang diterima oleh penulis pertama dan hibah Penelitian Terapan Unggulan Perguruan Tinggi yang diterima oleh penulis korespondensi. 


\section{DAFTAR PUSTAKA}

Abrol, D.P., A.K. Gorka, M.J. Ansari, A. Al-Ghamdi, S. AlKahtani. 2019. Impact of insect pollinators on yield and fruit quality of strawberry. Saudi J. Biol. Sci. 26: 524-530.

Al-Janabi, N.H., H.H. Al-karboli. 2017. Damage assessment of the pea blue butterfly Lampides boeticus L. (Lepidoptera: Lycaenidae) on cowpea (Vigna unguiculata). J. Biodivers. Environ. Sci. 11:268273.

Bommarco, R., L. Marini, B.E. Vaissière. 2012. Insect pollination enhances seed yield, quality, and market value in oilseed rape. Oecologia 169:1025-1032.

Crall, J.D., J. Brokaw, S.F. Gagliardi, C.D. Mendenhall, N.E. Pierce, S.A. Combes. 2020. Wind drives temporal variation in pollinator visitation in a fragmented tropical forest. Biol. Lett. 16:20200103.

Connelly, H., K. Poveda, G. Loeb. 2015. Landscape simplification decreases wild bee pollination services to strawberry. Agric. Ecosyst. Environ. 211:51-56.

De Cillis, F., B. Leoni, M. Massaro, M. Renna, P. Santamaria. 2019. Yield and quality of faba bean (Vicia faba L. var. major) genotypes as a vegetable for fresh consumption: A comparison between Italian landraces and commercial varieties. Agriculture 9:253.

De Luca, P., M. Vallejo-Marin. 2013. What's the 'buzz' about? The ecology and evolutionary significance of buzz-pollination. Curr. Opin. Plant Biol. 16:429435 .

Descamps, C., M. Quinet, A. Baijot, A. L. Jacquemart. 2018. Temperature and water stress affect plant-pollinator interactions in Borago officinalis (Boraginaceae). Ecol. Evol. 8:3443-3456.

Fohouo, F.N.T., A. Ngakou, B.S. Kengni. 2009. Pollination and yield responses of cowpea (Vigna unguiculata L. Walp.) to the foraging activity of Apis mellifera adansonii (Hymenoptera: Apidae) at Ngaoundéré (Cameroon). African J. Biotechnol. 8:1988-1996.

Gajc-Wolska, J., K. Kowalczyk, J. Mikas, R. Drajski. 2011. Efficiency of cucumber (Cucumis sativus L.) pollination by bumblebees (Bombus terrestris). Acta Sci. Pol. 10:159-169.

Hendriksma, H.P., A.L. Toth, S. Shafir. 2019. Individual and colony level foraging decisions of bumble bees and honey bees in relation to balancing of nutrient needs. Front. Ecol. Evol. 7:177.
Ige, O.E., O.F. Olotuah, V. Akerele. 2011. Floral biology and pollination ecology of cowpea (Vigna unguiculata L. Walp). Mod. Appl. Sci. 5:74-82.

Karapanos, I., A. Papandreou, M. Skouloudi, D. Makrogianni, J.A. Fernandez, E. Rosa, G. Ntatsi, P.J. Bebeli, D. Savvas. 2017. Cowpea fresh pods - a new legume for the market: assessment of their quality and dietary characteristics of 37 cowpea accessions grown in southern Europe. J. Sci. Food. Agric. 97: 4343-4352.

Klatt, B., A. Holzschuh, C. Westphal, Y. Clough, I. Smit, E. Pawelzik, T. Tscharntke. 2014. Bee pollination improves crop quality, shelf life and commercial value. Proc. Biol. Sci. 281:20132440.

Klein, A.M., I. Steffan-Dewenter, T. Tscharntke. 2003. Fruit set of highland coffee increase with the diversity of pollinating bees. P. Roy. Soc. B-Biol. Sci. 270:955961.

Kowalska, G. 2008. Flowering biology of eggplant and procedures intensifying fruit set. Rev. Acta Sci. Pollut. Hortorum Cultus. 7:63-76.

Leksikowati, S.S., R.E. Putra, M. Rosmiati, I. Kinasih. 2018. Aplikasi Trigona (Tetragonula) laeviceps sebagai Agen Penyerbuk pada Sistem Tumpang Sari Buncis dan Tomat di dalam Rumah Kaca. J. Sumberd. Hayati 4:63-70.

Oyelana, O.A., K.O. Ogunwenmo. 2012. Floral biology and the effects of plant-pollinator interaction on pollination intensity, fruit and seed set in Solanum. African J. Biotechnol. 11: 14967-14981.

Pellegrino, G., D. Gargano, M. Noce, A. Musacchio. 2005. Reproductive biology and pollinator limitation in a deceptive orchid, Serapias vomeracea (Orchidaceae). Plant Species Biol. 20:33-39.

Polatto, L.P., J. Chaud-Netto, J.C.S. Dutra, V.V.A. Junior. 2012. Exploitation of floral resources on Sparattosperma leucanthum (Bignoniaceae): foraging activity of the pollinators and the nectar and pollen thieves. Acta Ethol. 15:119-126.

Potts, S.G., J.C. Biesmeijer, C. Kremen, P. Neumann, O. Schweiger, W.E. Kunin. 2010. Global pollinator declines: trends, impacts and drivers. Trends Ecol. Evol. 25:345-353.

Proctor, M., P. Yeo, A. Lack. 2012. The Natural History of Pollination (Collins New Naturalist Library). Harper Collins Publishers, UK. 
Putra, R.E., J. Subagio, I. Kinasih, A.D. Permana, M. Rosmiati. 2017. Pola kunjungan serangga liar dan efek penambahan koloni Trigona (Tetragonula laeviceps Smith) pada penyerbukan kabocha (Cucurbita maxima). J. Entomol. Indonesia 14:69-79.

Reswari, H.A., M. Syukur, W.B. Suwarno. 2019. Kandungan antosianin dan karotenoid serta komponen produksi pada kacang panjang berpolong ungu dan hijau. J. Agron. Indonesia 47:61-67.

Ruslan, W., Afriani, Miswan, Elijonnahdi, Nurdiyah, M. Sataral, Fitrallisan, Fahri. 2015. Frekuensi kunjungan lebah Apis cerana dan Trigona sp. sebagai penyerbuk pada tanaman Brassica rapa. J. Nat. Sci. 4:65-72.

Sawe, T., K. Eldegad, O. Totland, S. Macrice, A. Nielsen. 2020. Enhancing pollination is more effective than increased conventional agriculture inputs for improving watermelon yields. Ecol. Evol. 10:53435353.

Soetiarso, T. 2010. Persepsi dan preferensi konsumen terhadap atribut produk beberapa jenis sayuran minor. J. Hort. 20:299-312.

Stein, K., I. Hansen. 2011. Potential pollinators and robbers: A study of the floral visitors of Heliconia augusta (Heliconiaceae) and their behaviour. J. Pollinat. Ecol. 4:39-47.

Stephanie, K.B., N. Albert, T. Fohouo. 2015. Pollination and yield attributes of (cowpea) Vigna unguiculata L. Walp. (Fabaceae) as influenced by the foraging activity of Xylocopa olivacea Fabricius (Hymenoptera: Apidae) and inoculation with Rhizobium in Ngaoundere, Cameroon. Int. J. Agron. Agric. Res. 6:62-76.
Ssymank, A., F. Gilbert. 1993. Anemophilous pollen in the diet of Syrphid flies with special reference to the leaf feeding strategy occurring in Xylotini (Diptera, Syrphidae). Dtsch. Entomol. Zeitschrift 40:245-258.

Tan, K., T. Latty, S. Dong, X. Liu, C. Wang, B.P. Oldroyd. 2015. Individual honey bee (Apis cerana) foragers adjust their fuel load to match variability in forage reward. Sci. Rep. 5:1-7.

Udayani, I.G.A., N.L. Watiniasih, I.K. Ginantra. 2020. Koloni lebah madu (Apis cerana F.) sebagai agen penyerbuk pada tumbuhan terung ungu (Solanum melongena L.) pada sistem pertanian lokal Bali. J. Biol. Sci. 7:17-20.

Venkateswarlu, J., M.K. Rao. 1972. Breeding system, crossability relationship, and isolating mechanism in the Solanum nigrum complex. Cytologia. 37:317326.

Wousla, E.N., M. Andargie, R.S. Pasquet, M. Mondon, V. Menez, C. Cochin, L. Paul, L. Pardon, M. Roubaud. 2020. Is bigger better? Apidae (Xylocopinae), megachilidae and cowpea (Vigna unguiculata) pollination. Plant Breed. 139:156-166.

Wulandari, A.P., T. Atmowidi, D.S. Kahono. 2017. Peranan lebah Trigona laeviceps (Hymenoptera: Apidae) dalam produksi biji kailan (Brassica oleracea var. alboglabra). J. Agron. Indonesia 45:196-203.

Yulianti, N, E. Santosa, A.D. Susila. 2018. Production of fruits and leafy vegetables Solanum nigrum Linn under different shade levels. J. Trop. Crop Sci. 5:6472 . 